\title{
Introduction: Jewish Conditions, Theories of Nationalism
}

\author{
Shana Cohen ${ }^{1} \cdot$ John A. Hall ${ }^{2}$
}

Published online: 14 February 2017

(C) Springer Science+Business Media New York 2017

\begin{abstract}
Thinkers with Jewish backgrounds, whether ascribed, embraced or even denied, created the central grammar used in modern attempts to understand nationalism. This introduction first describes the central dilemma faced by those with Jewish conditions when confronted by the rise of ethnonationalism. The responses to the dilemma were varied, so the bulk of this introduction describes some of the most important intellectual boundariesdoing so in such a manner as to introduce the specialist studies that then follow.
\end{abstract}

Keywords Nationalism $\cdot$ Empires $\cdot$ Jews $\cdot$ Liberalism $\cdot$ Zionism

\section{Statement of Intent}

European thinkers with Jewish backgrounds, whether ascribed, embraced or denied, experienced nationalism in the most visceral ways imaginable. Their reactions to and theorizations of this new political form were varied and complex and were of enormous interest for identity options in the modern world. Such thinkers did most to create the grammar with which we think about nationalism, yet few have systematically studied this. ${ }^{1}$ The purpose of this special issue is to develop an angle of inquiry. The agenda of possible research is very large, but this issue makes a decisive contribution to it in two ways. First, this introduction hints at some of the boundaries of this social world. Second, the individual papers focus in detail on important cases within it as we will show, thereby showing the sort of findings that are possible within this frame.

${ }^{1}$ An exception is Riga and Hall (2016). The categories noted here follow this important essay.

John A. Hall

john.anthony.hall@mcgill.ca

Shana Cohen

Sc736@cam.ac.uk

1 Department of Sociology,, University of Cambridge, The Old Schools, Trinity Lane, Cambridge CB2 $1 \mathrm{TN}, \mathrm{UK}$

2 Department of Sociology, McGill University, 855 Sherbrooke Street West, Montreal, QC H3A 2T7, Canada 
The focus here is primarily on the two generations of Jewish thinkers, largely from (east) central Europe and Russia, whose formative intellectual years were the last decades of the nineteenth century and the early decades of the twentieth century. Two disclaimers are needed. First, thinkers of this period who did not have Jewish backgrounds also contributed to our understanding of nationalism. Hence, the claim being made is about disproportion rather than exclusivity. Second, it is important not to essentialize Jewishness. Is it right to put the matter pointedly and to consider someone Jewish who is secular, wholly bereft of cultural loyalty to the religion of his ancestors, and who holds no such self-ascription? Social scientists should avoid reification. But care need not block inquiry. On the one hand, our interest is in choices and theorizations, thereby bringing us in line with the demand for biographical specificity. On the other hand, many categories that concern social science are real-actually existing and experienced as such. Ascription can make actors deal with Jewish dilemmas even if they wished to avoid them or felt that they had left such circumstances far in their own past.

\section{The Central Dilemma}

The situation facing Jews changed at the end of the eighteenth century. The granting of citizenship rights by the French Revolution allowed Jews the possibility of belonging. One consequence was gratitude for being allowed to enter nation-states and, accordingly, both a diminution in attachment to Judaism and the breaking of transnational loyalties. Yet Jewish confessional fragmentation into national social worlds meant differentiated attachments to states; how and when nation-states crystallized shaped Jewish positioning vis-à-vis emerging nationalisms. The route to a nation-state was slow and organic in France and England because 'state' came before 'nation' (Mann 1995). In contrast, the fact that nation came before the nation-state in the multiethnic empires put Jews under pressure. The key dilemma is the change of tenor in the spirit of nationalism, from putatively liberal to something rather different, namely anti-Semitic ethnonationalism. Ernest Gellner put the matter with characteristic verve:

....what [ethnonationalists] hate above all else are just those damned cosmopolitans, who lack roots of their own and wish to impose their rootlessness on others, and try to make it a universal norm in virtue of some grey general humanity. These rootless people are, not surprisingly, engaged in activities such as trade or thought, which lead them to these bloodless values. But that is not for us, say the romantic nationalists: we are rooted to the soil...we feel, we do not calculate... and we spurn those who do...(Gellner 1998:19).

This is the classic late nineteenth century cultural blending of the romantic search for authenticity with social Darwinism. This insistence on belonging placed Jewish minorities in a difficult position. Gellner continued, when stressing the obvious choice for Jews, between assimilation and Zionism:

... the minority had no illusion of its own to go back to. It only had the recollection of the ghetto, which by definition was not a self-sufficient community or culture at all, but an unromantically (commercially) specialized sub-community of a wider world within which it was pejoratively defined. Although in fact a literary populist nostalgia for the shtetl does exist nevertheless, Jewish populist Romanticism is in the end a contradiction in terms ...So the romantic reaction placed the Jews in a dilemma far sharper than the 
Enlightenment had done. They were largely deprived of the illusion of a possible return to the roots, an illusion indulged by their gentile neighbours with enthusiasm and conviction. Thou shalt not covet thy neighbour's Gemeinschaft! But, of course, one does. So what's to be done? The options that were logically open were either to infiltrate the Other's Gemeinschaft or to create a new one of one's own, whether or not there had been any peasants available for the past two millennia, who could define its folk culture (1987: 78).

The insistence on the authenticity of roots and theorizations of the assimilationist choice are central, but two more choices that we will mention are equally important. Before turning to them, however, attention must be given to two complications to the basic dilemma.

The most immediate complication involves the consequences of generational choices and theorizations made in the light of emancipation's possibilities and constraints. However, clichéd, 'fathers' did hand 'sons' something against which to react-often experienced as either too much Judaism or too much assimilationist cosmopolitanism. Generational choices became part of inherited internal geographies; the boundaries of assimilation did not stand still, particularly as the available repertoires of belonging and integration multiplied. Geopolitical events caused a further complication. After the First World War, theorizations became urgent because the fluidity of multiple and overlapping religious, cultural and linguistic identities began to crystallize around more fixed identifications of ethnicity or nationality. Nevertheless, the political space theorized by thinkers shaped by the late nineteenth century - Otto Bauer, Leon Trotsky and Vladimir Jabotinsky, Karl Polanyi, Lewis Namier, Georg Lukacs and Hans Kohn - remained multiethnic, often aligned with social democratic critiques and attempts to fix and re-design empires. Later thought was less a product of empire than of ethnonationalizing states and hideous expulsions. The subsequent generation of thinkers born in the first decades of the twentieth century-Karl Popper, Berlin and Karl Deutsch, and latterly Gellner and Elie Kedourie — was shaped by late-Habsburg liberalism and post-Tsarist socialism. This was the most secular generation: liberals and anti-communist intellectuals shattered by the realization that the late nineteenth century liberalism was less a secure product of social evolution than a benign historical oddity (Hacohen 2000).

But the dilemma facing those with Jewish conditions goes well beyond these two groups, and this issue concludes with an essay on an important thinker of a later generation who was born outside Europe - on whose position we comment immediately. The complexities in the case of Hélène Cixous are very great, based not just on a Jewish background, but quite as much on experiences as a woman, as a child within pre-independence Algeria and as an immigrant within France. Sami Everett shows how the recovery of Algerian childhood has reinforced distaste for any totalizing and homogenizing conception of French identity and this despite her loyalty to secular ideals. But the larger point that comes through is her determination to resist any singular sense of belonging, to embrace instead ambiguity and porousness - overlapping spaces of self-reflection and identification that avoided at all cost any essentialism of religious and national identity.

\section{Choices}

The distinctive eras and atmospheres within the European sphere created four general theoretical frames, illustrated here by exemplars. Please note that the categories do not cage 
individuals, as is already so obvious from the later case of Cixous. Some other thinkers attempted to occupy two positions at the same time, sometimes thereby creating confusion within their social theories. Others moved very rapidly between positions. This is especially true in the case of Hans Kohn and Lewis Namier, both considered in this issue-but treated differently in this introduction. Adi Gordon's essay concentrates on an important but very particular early period of Kohn's career, but we add to it here some comments about his intellectual journey as a whole, thanks to the appearance of Gordon's intellectual biography of this founding father of nationalism, the first to treat his life and work (Gordon 2017). The twists and turns of Namier's career are mentioned in detail in David Hayton's essay in this volume, so only occasional commentary is required in this case - though here, we too can look forward to the future appearance of Hayton's biography of the great historian and intellectual.

\section{Assimilation and Erasure}

One response to ethnonationalism's dilemmas was assimilation. The attachments implied in the assimilationist choice could of course be principled, based on genuine admiration for what was believed to be a high culture. But was instrumentally motivated assimilation merely opportunism to be distrusted because it lacked conviction? Could invisible roots be uncovered for those who had converted? These challenges could involve attempts at total erasure, with the internal Jewish charge of self-hatred often aimed less at those seeking exit from Jewishness than at those seeking to erase it. To gain entry to a society requires two background conditions, release by the group to which one belongs and acceptance by the group one wishes to join. Isaiah Berlin captured the difficulties that could result for Jews when seeking entry in two famous essays, 'Benjamin Disraeli, Karl Marx and the Search for Identity' and ' Jewish Slavery and Emancipation'. In the first, he noted that an outsider seeking entry gains such expertise on local rules as thereby to make him an object of suspicion. 'The search for security seems to those who are secure a symptom of abnormality, and often irritates them' (Berlin 1979: 256). The second essay continued the line of argument by considering Jews as hunchbacks - at times denying they had a hump, on other occasions celebrating it, with a further contortion in seeking to hide it altogether (Berlin 2000). Gellner made similar points in his private notes: 'We mid European Jews - exactly like man according to existentialism choosing attributes, being given none. Human situation, only somewhat more so. Unfortunately, it is of the essence of those attributes that they are not chosen but given. If chosen, are somehow false. Not surprisingly, a mainly descent- based society values givenness of attributes more than endeavour, contrary to Kant' (in Hall 2010: 87-8). Both thinkers accepted that these existential pressures could lead to self-hatred and to accepting the standards of others as part of a visceral desire to escape one's past, whether real or ascribed. A minimal claim can be that of disloyalty to one's cultural heritage, abandoning much of great value (Birnbaum 2008). But the charge can carry much more weight: It can be seen as the Jewish community condemning its own, making it hard for an individual to leave. Malachi Hacohen's earliest treatment of Popper noted not just anti-Zionism but touches of anti-Semitism in a riveting critique that stressed the loneliness that came from dreaming of the open society and failing to appreciate the home that Zionism offered (Hacohen 1996). Still, the most ubiquitous choice was the generalized patriotism stressed by David Aberbach in this issue (cf. Aberbach 2013). It is important to underline his insistence that 'Jewish patriotism was compatible with Zionism - indeed many of its leaders gave patriotism as a reason for their Zionism' (Aberbach 2013: xxxiii). Still, Emile Durkheim stands as a particularly clear exemplar of this position as a 
whole. When asked by the city of Paris in 1916 as to the policy towards incoming Russian Jews and animated by a cultural confidence from within an assimilated experience, Durkheim argued that Russian Jews' voluntary conscription and war death rates demonstrated exceptional patriotism since they understood very well how much they owed France (Elkarati 1990). This led to anti-Semitic comments being directed against the French sociologist for the reason stressed so clearly by Aberbach: to suggest that one could join a nation was to imagine a common humanity, a position diametrically opposed to the ethnonationalist claim that only blood gave belonging.

\section{Wider Worlds, Real and Imaginary}

Europe's political space at the turn of the nineteenth century was filled not just by national states slowly morphing into nation-states but also by the great land empires of the Habsburgs and Romanovs. Thinkers with Jewish backgrounds increasingly felt themselves attracted to such entities. Five separate positions can be distinguished.

Some sought Jewish autonomy within composite political frameworks. This was true of Joseph Samuel Bloch in Vienna; he imagined a civic Austrianness that could retrieve Jewishness from its emancipationist relegation to confessional status and enable Jews to exist as an ethnicity within wider political frames (Reifowitz 2003). In the Tsarist Empire, Yiddishists' attempts to gain official 'national' recognition represented a similar version of this kind of national accommodationism (Karlip 2013).

A second and slightly different attempt to deal with multiethnicity was proposed by Austrian socialists keen to reform the late Habsburg Empire by detaching national consciousness from territory. The leading figures of this de-territorialized conception of nationalism were Karl Renner and Otto Bauer, both figures of great importance in the later Austrian history as well as direct intellectual influences on the Bolsheviks. Ian Reifowitz's first describes their ingenious general position and then draws a distinction between the two thinkers. Bauer's ambivalence about his Ostjuden background, his insecurity about his own newly Germanized identity, resulted in the rejection of an articulated sense of nationhood for Jews with which Renner was wholly comfortable. This is a prime example of nervousness, even self-hatred identified by Berlin that was discussed earlier.

A third position was that of the left-wing empire savers such as the early Bolsheviks. Slightly different from the Austro-Marxists, their prescriptions involved a more thoroughgoing reshaping of the social conditions held to have given rise to nationalism (Riga 2012: Chapter 3).

A fourth position within these wider worlds was that of the cosmopolitan dreams of empire. Perhaps the greatest theorist here was Popper: his cosmopolitanism was, so to speak, the total privileging reason above all else. This distinguishes him from Elie Kedourie, his colleague at the London School of Economics. Popper's philosophy was positive, seeking to re-create a cosmopolitan world in a different guise; Kedourie insisted that we submerge ourselves in a tradition of political wisdom, repudiating abstract reason at all costs (O’Leary 2002).

The final position sought to create new kinds of world order so as to defang nationalism. Karl Polanyi stressed that capitalism constantly causes disruptive change, making it likely that societies would seek to protect themselves from the market. His interpretation of the twentieth century argued that precisely this occurred, with protection being provided by the Nazis for Germans traumatized by war, inflation and the Great Depression. In his late years, Polanyi moved towards positive prescriptions, urging the creation of 'tamed empires' able to interact 
peacefully (Dale 2016). The same intellectual drive can be seen in a different form in Karl Deutsch's work on what he termed security communities (Deutsch et al. 1957). The basic idea is clear: a shared system of values would allow for high levels of co-operation between a set of states - the recreation of Austro-Hungary in a new guise.

\section{Liberalism and the Nation-State}

The creation of new nation-states in Europe as the result of imperial collapse combined with the horrors of ethnic cleansing, population transfers and the Holocaust placed at the centre of attention the simplest of questions: How can the nation-state be made safe from the horrors of nationalism? Many in effect worked to respond to the brutal implications of Gellner's celebrated definition of nationalism in which each nation has its own state and each state its own nation. Might there be ways of loosening this tight, homogenizing formula so as to make life bearable for those with Jewish backgrounds?

The career of Hans Kohn is of especial interest (Gordon 2017). A Jewish background in Prague made Jewish concerns immediately central in the years before 1914 because a move towards the German community was almost completely blocked due to the rise of German ethnonationalism in Bohemia. Gordon's paper in this issue describes the way in which Kohn's early membership in Bar Kochba stressed the need for spiritual renewal, considering Jews at that time in the most essentialist way imaginable. But the experience of war and of the collapse of the Habsburg Empire led to political commitments replacing cultural longings, allowing Kohn to leave behind his early essentialism. Kohn's greatest hope was for the survival of multinational states (Gordon 2017). Hence, the creation of new nation-states led him to move to Palestine, to participate in the Zionist adventure. But by 1934, he had become deeply disillusioned. Zionism had held the ideological promise in his eyes of inclusion, of the possibility of a bi-national state. As it became ever clearer that a Jewish state would seek to be as homogeneous as new nation-states of Central Europe, he left for the United States. The rest of his career was devoted to the most famous distinction in the theory of nationalism, namely that between civic and ethnic nationalism. This stark opposition represents a Cold War warrior's commitment to liberal values and the hope that these would be shared by new nations, combined with the fear that some political cultures would always think with their blood.

A rather different argument for liberalism in the nation-state came from Berlin. His position was made especially clear in his response to an interview with Arthur Koestler in which the Hungarian exile claimed that the foundation of Israel meant that Jews should either go to Israel or totally assimilate in the countries in which they lived (Berlin 2000). Berlin was well aware of Jewish conditions, not least as he admired Lewis Namier, and he certainly felt that the foundation of Israel made a huge difference to Jewish self-perception. But he wished to remain in the diaspora and so argued for integration rather than assimilation - that is, for difference, the right to one's religion or ethnicity and the insistence on the right to hold multiple identities. This liberal nationalism was famously justified by Berlin by reference to Herder (Birnbaum 2008: Chapter 6; Hacohen 2012).

Though there is much to admire here, his viewpoint has been subject to serious criticism. There is surely an unresolved contradiction between Berlin's stress on pluralism inside states and his hope that different states would preserve distinct cultures. What is at issue here is an element of essentialism, recognized in Hacohen's most recent work on Popper. This new work represents something of a change of heart on Hacohen's part, stressing as it does elements of great moral merit in Popper's position: 
In acculturation, Popper saw an opportunity, not a threat. The encounter with the Other, with the foreign and the new, with the different and unexpected, was often uncomfortable, but it was exciting, an opportunity to learn and expand - to change. Like scholarly criticism, it was the sine qua non for progress. At the height of Thomas Kuhn's popularity, when his incommensurable scientific paradigms - worldviews which made arbitrating evidence impossible because they spoke different languages - were used to explain difficulties in cultural exchange, Popper insisted that paradigms were myths: Communication across cultures was always possible, although not easy. He preferred empires to nation states because they encouraged cross-cultural interaction, the litmus test of the Open Society. The cosmopolitan commonwealth opened up closed communities and loosened ethnocultural identities. To Berlin's Herderian mosaic of closed ethnic cultures, Popper counter-posed a dynamic Open Society, a liberal cosmopolitan alternative (Hacohen 2012: xx).

Popper's view is sociologically realistic given that so many Jews had made their contribution by assimilating to larger worlds. The charge against Berlin is then, as noted, that of essentialism. Ernest Gellner's position differed from Popper's both personally and intellectually: a childhood in Prague had led him to like nationalism whose appearance he saw as a structural necessity rather that a reversion to the womb. But he agreed with and added to the charge of essentialism in his own extended consideration of Berlin's work (Hall 2010: 84-94).

Care should be taken with these criticisms. F. Scott Fitzgerald noted somewhere that the sign of a first class mind is the ability to function whilst aware of the sense of conflicting positions. It is exactly this case that made by Joshua Cherniss in his treatment of Berlin in this special issue, stressing necessary and fertile tensions rather absolutist criticisms leading to jejune dismissal.

\section{Authenticity and Essentialism}

Although the essentialist position has been noted in connection with Berlin and Kohn, it is worth exploring through figures who theorized Zionism as a form of nationalism. Viewed through the lens of Jewish conditions, an insistence on a return to essentialized roots stood in opposition to the kinds of constructivist attempts at assimilation described above. Jabotinsky, for instance, maintained that tribal essentialism was the only true response to the 'tragic illusiveness of the assimilationist choice' (Mogilner 2013, November 18-19: 37. Cf. Halkin 2014). One consequence of this essentialist theorization was that its identity implications could make assimilated Jews uncomfortable. But another was that it allowed release from difficult dilemmas because it removed the instrumentalism or opportunism implied in the assimilationist choice. The essentialist position required a complete submersion into one's 'own' nation.

Yet inconsistencies could be apparent. Kohn's early cultural Zionist essentialism in Bar Kochba, Jabotinsky's later essentialism in a revisionist Zionism and Namier's anti-Polish Zionism paradoxically had no theoretical space for their own existing assimilation. Their theoretical espousal of authenticity was itself a product of the mixing of assimilation. Of course, Zionism was not incompatible with forms of assimilation, as Namier's simultaneous Zionist and British loyalties show (cf. Aberbach 2013). But it also emerged entwined with other late nineteenth century European nationalisms, in response not only to anti-Semitism but also to disillusionment with the Haskalah, to the difficult lives of the Ostjuden, to the ethnicization of Jewishness and to the intellectual contents of the fin-de-siècle, including 
organicism, secularism and spiritual renewal. Unlike those for whom wider worlds were appealing, here, a shared aversion to empire — in all its forms - was evident. Jabotinsky and Kohn's pre-Holocaust, pre-state Zionism envisioned bi-national arrangements in a Jewish and Arab Palestine, but these were nevertheless based on two essentialized cultures. Kohn's early cultural and spiritual Zionism was rooted in the anti-assimilationist, anti-imperialism of a Hapsburg Prague generation (Gordon 2017); Namier's consistent anti-Polishness paralleled his anti-Habsburg stance (Colley 1989); Jabotinsky rejected composite political frames precisely because they led to assimilation and cultural mixing (Mogilner 2013, November 18-19).

\section{Conclusion}

A reflection of the state of the theory of nationalism can usefully extend and close this discussion. Bluntly, not all the theories mentioned here have proven to have much merit. Indeed, negative points force themselves upon us. Neither assimilation nor linguistic/cultural autonomy worked at all easily or automatically in the world of emergent nation-states. Equally, empire saving visions, whether of the early Bloch or Bauer or the later Bolshevik experiment, came to nothing. Furthermore, once Jewishness had lost the historic confessional mooring that had enabled a certain kind of integration, assimilation dilemmas shifted because Jews had become an ethnic nation like others, though crucially one without territory. Of course, there was then little space for nations within nations. So dreams of wider non-ethnically homogeneous worlds, liberal or socialist, mostly fared badly. The visions of Popper and Kedourie also amounted to little: they were too abstract for real human beings and descriptively either nostalgic or a rationalist misreading of how past empires actually worked. Kohn's final ethnic-civic distinction offered no additional guidance largely because many civic nationstates have ethnic cores, something his own Zionism recognized experientially if not intellectually. Finally, essentialism precludes real understanding of the very pervasive social and historical fact of assimilation, weakening it as an accurate theory of nationalism.

But there are exceptions that allow positive points to be made. Berlin and Gellner do advance the agenda of nationalism studies. Of course, they reveal each other's weaknesses - the toughness of Gellner's definition challenged by Berlin's concern with integration, the philosophical weakness of the historian ideas of ideas challenged by the philosopher (Hall 2010: Chapters 3 \& 10). But both suggest, though neither fully theorizes, the possibility that liberal arrangements may allow for several nations to live under a shared political roof-perhaps the most vital issue of contemporary world politics. But the specificities that their work lacks can be noted. Constitutional design by federal and consociational means merits attention as it is becoming sophisticated. Crucially, the diminution of levels of geopolitical conflict gives one hope that stable international conditions may allow states to be less unitary and homogeneous. But liberal design is never easy; much remains to be done.

\section{References}

Aberbach, D. (2013). The European Jews, patriotism and the liberal state 1789-1939. London: Routledge. Berlin, I. (1979). Against the current: essays in the history of ideas. London: the Hogarth Press.

Berlin, I. (2000). The power of ideas. London: Chatto and Windus. 
Birnbaum, P. (2008). Geography of hope: exile, the enlightenment, disassimilation. Stanford: Stanford University.

Colley, L. (1989). Lewis Namier. London: Weidenfeld and Nicolson.

Dale, G. (2016). Karl Polanyi: a life on the left. New York: Columbia University.

Deutsch, K. W., Burrell, S. A., Kann, R. A., Lee, M., Lichterman, M., Raymond, L., Loewenheim, F. L., \& van Wagenen, R. (1957). Political community in the North Atlantic Area: international organization in the light of historical experience. Princeton: Princeton University.

Elkarati, N. (1990). Emile Durkheim, defenseur des refugies russes en France. Rapport sur la situation des russes du department de la Seine [Emile Durkheim, defender of Russian refugees in France. Report on the situation of Russians in the Department of the Seine]. Geneses, 2, 168-177.

Gellner, E. A. (1987). Culture, identity and politics. Cambridge: Cambridge University.

Gellner, E. A. (1998). Language and solitude: Wittgenstein, Malinowski and the Habsburg dilemma. Cambridge: Cambridge University.

Gordon, A. (2017). Towards nationalism's end: an intellectual biography of Hans Kohn 1891-1971. Waltham: Brandeis University Press.

Hacohen, M. (1996). Karl Popper in exile: the Viennese progressive imagination and the making of The Open Society. Philos Soc Sci, 26, 452-492.

Hacohen, M. (2000). Karl Popper-the formative years, 1902-45: politics and philosophy in interwar Vienna. Cambridge: Cambridge University.

Hacohen, M. (2012). Berlin and Popper between nation and empire: diaspora, cosmopolitanism and Jewish life. Jewish Historical Studies, 44, 51-74.

Halkin, H. (2014). Jabotinsky: a life. New Haven, CT: Yale University.

Hall, J. A. (2010). Ernest Gellner: an intellectual biography. London: Verso.

Karlip, J. (2013). The tragedy of a generation: the rise and fall of Jewish nationalism in Eastern Europe. Cambridge (MA): Harvard University.

Mann, M. (1995). A political theory of nationalism and its excesses. In S. Periwal (Ed.), Notions of nationalism. Budapest: Central European University.

Mogilner, M. (2013). Sacrificial postcoloniality: Russian contexts of the anti-imperial nationalism of Vladimir Jabotinsky. Paper presented at Ab Imperio Workshop Series 'Postimperial and Postcolonial Crossroads: the Scandal of the City', University of Illinois at Chicago.

O’Leary, B. (2002). In praise of empires past: myths and methods of Kedourie's nationalism. New Left Rev, 18, 106-130.

Reifowitz, I. (2003). Imagining an Austrian nation: Joseph Samuel Bloch and the search for a multiethnic Austrian identity 1848-1919. New York: Columbia University Press.

Riga, L. (2012). The Bolsheviks and the Russian Empire. New York: Cambridge University.

Riga, L., \& Hall, J. A. (2016). Jewish conditions, theories of nationalism: cartographical notes. Nations and Nationalism, 22(2), 371-390. 